\title{
Follow-up of dairy cattle naturally infected by Trypanosoma vivax after treatment with isometamidium chloride
}

\author{
Acompanhamento de bovinos leiteiros naturalmente infectados com \\ Trypanosoma vivax após tratamento com cloreto de isometamidium
}

\author{
Kayo José Garcia de Almeida Castilho Neto'; Ana Beatriz da Cruz Favaro Garcia'; \\ Otavio Luiz Fidelis Junior2; Walter Beterquini Nagata3; Marcos Rogério André1; Marta Maria Geraldes Teixeira4; \\ Rosangela Zacarias Machado'; Fabiano Antonio Cadioli1,3* [C] \\ ${ }^{1}$ Faculdade de Ciências Agrárias e Veterinárias - FCAV, Universidade Estadual Paulista - UNESP, Jaboticabal, SP, Brasil \\ ${ }^{2}$ Departamento de Medicina Veterinária, Universidade de Vila Velha - UVV, Vila Velha, ES, Brasil \\ ${ }^{3}$ Escola de Medicina Veterinária Medicine, Universidade Estadual Paulista - UNESP, Araçatuba, SP, Brasil \\ ${ }^{4}$ Instituto de Ciências Biomédicas, Universidade de São Paulo - USP, São Paulo, SP, Brasil
}

How to cite: Castilho Neto KJGA, Garcia ABCF, Fidelis Junior OL, Nagata WB, André MR, Teixeira MMG, et al. Follow-up of dairy cattle naturally infected by Trypanosoma vivax after treatment with isometamidium chloride. Braz J Vet Parasitol 2021; 30(1): e020220. https://doi.org/10.1590/S1984-29612021019

\begin{abstract}
Trypanosoma vivax infections cause nonspecific clinical signs in cattle associated with aparasitemic intervals, making disease diagnosis a challenge. In Brazil, diminazene aceturate and isometamidium chloride (ISM) are available to treat bovine trypanosomosis. The objective of this study was to follow-up, by molecular and serological techniques, dairy cattle naturally infected by $T$. vivax after ISM treatment. Thirty cattle naturally infected with $T$. vivax received two applications of ISM, at a dosage of $1.0 \mathrm{mg} / \mathrm{kg}$ intramuscularly, on days 0 and 150 . For T. vivax diagnosis, EDTAblood and serum samples were evaluated on $0,7,15,30,60,90,120,150,180,210$, and 240 days after treatment PCR, Loop-mediated isothermal amplification (LAMP) and ELISA. Animals with persistent detection of $T$. vivax DNA by both PCR and LAMP were found and continuous detection of anti-T. vivax IgG antibodies by ELISA, suggesting the presence of $T$. vivax resistance to ISM. The combination of LAMP and ELISA tests can prevent misdiagnosis of the parasite clearance in treated cattle, contributing to better disease control. This is the first experiment that demonstrates the persistence infection of $T$. vivax under ISM treatment in a natural infected herd and evidence of ISM chemotherapy-resistant T. vivax in Brazil.
\end{abstract}

Keywords: Trypanosomosis, diagnosis, serology, LAMP, clearance.

\section{Resumo}

Em bovinos, infecções por Trypanosoma vivax geram sinais clínicos inespecíficos que, associados a intervalos aparasitêmicos, faz com que o diagnóstico da enfermidade seja desafiador. No Brasil, somente aceturato de diaminazeno e cloridrato de isometamidum (ISM) estão disponíveis para o tratamento da tripanossomose bovina. Este trabalho teve como objetivo acompanhar bovinos leiteiros naturalmente infectados por T. vivax, após o tratamento com ISM por meio de técnicas moleculares e sorológica. Foram utilizados 30 bovinos naturalmente infectados com T. vivax, sendo estes tratados com duas aplicações de ISM, na dosagem de 1,0 mg/kg por via intramuscular profunda, nos dias 0 e 150. Foram avaliadas, para diagnóstico de $T$. vivax, amostras de sangue acrescido de EDTA e soro, colhidas nos 0, 7, 15, 30, 60, 90, 120, 150, 180, 210 e 240 dias após os tratamentos pela reação em cadeia da polimerase (PCR), amplificação circular isotérmica do DNA (LAMP) e ensaio de imunoabsorção enzimático (ELISA). Verificou-se a presença de animais com persistência na detecção de DNA de T. vivax pela PCR e LAMP, bem como detecção contínua de anticorpos IgG anti-T. vivax pelo método de ELISA, sugerindo a presença de resistência de T. vivax ao ISM. A combinação dos testes LAMP e ELISA pode evitar falsos diagnósticos da 
eliminação do parasita nos bovinos tratados, contribuindo para um melhor controle da doença. Este é o primeiro experimento que demonstra infecção persistente do T. vivax em rebanho naturalmente infectado, tratado com ISM, e evidencia possível resistência ao quimioterápico no Brasil.

Palavras-chave: Tripanossomíase, diagnóstico, sorologia, LAMP, eliminação.

\section{Introduction}

Trypanosomosis is caused by protozoa belonging to the Trypanosoma genus that infect domestic and wild animals. Trypanosoma vivax, T. evansi, T. theileri and T. cruzi are responsible for animal trypanosomosis in Central and South America (Jones \& Dávila, 2001; Dávila et al., 2003). Trypanosoma vivax infects many domestic and wild ungulates; indeed, it is the principal etiological agent of trypanosomosis in cattle, being responsible for substantial economic losses in cattle rearing in South America (Seidl et al., 1999; Jones \& Dávila, 2001).

The diagnosis of bovine trypanosomosis caused by T. vivax can be performed by clinical examination associated with parasitological, serological, and molecular methods. However, the diagnosis becomes challenging due to the lack of nonspecific clinical signs (Cadioli et al., 2012; Fidelis et al., 2016) and the presence of low parasitemia or aparasitemic periods (Fidelis et al., 2016). Serological methods, such as ELISA, represent an essential tool for screening of T. vivax exposure at the herds level (Cuglovici et al., 2010), but do not allow neither to discriminate animals with active infection from those treated and cured (Nantulya, 1990) nor to identify infected animals during the first days of infection (Fidelis et al., 2019). On the other hand, molecular methods, such as PCR (Cortez et al., 2009; Pimentel et al., 2012) and LAMP (Njiru et al., 2011), show a high capability for T. vivax DNA detection, even in periods supposedly considered as aparasitemic (Cadioli et al., 2015).

Diminazene aceturate (DA) and isometamidium chloride (ISM) are the two trypanocidal drugs licensed by the Ministry of Agriculture, Livestock, and Supply (MAPA) for T. vivax treatment in Brazil. However, there are reports of South American T. vivax strains refractory to DA in French Guiana (Desquesnes et al., 1995) and evidence of resistance in Brazil (Cadioli et al., 2012; Bastos et al., 2017). Despite the existence of reports on T. vivax resistance to ISM in African isolates (Giordani et al., 2016), in Brazil, until now, there is only one paper on the susceptibility of T. vivax in farm animals, which reports that ISM was effective in the clearance of parasites in experimentally infected cattle (Bastos et al., 2020). On the other hand, there are no studies on the susceptibility of T. vivax to ISM in naturally infected cattle in Brazil, as well as the use of LAMP to monitoring the parasitological cure after treatment. Thus, the present study aimed to follow-up dairy cattle naturally infected by T. vivax after ISM treatment, by both molecular and serological methods, to verify parasitological cure.

\section{Material and Methods}

The present study was approved by the Animal Use Ethics Committee (CEUA) of the School of Agricultural and Veterinary Studies (FCAV), São Paulo State University (Unesp), Jaboticabal, under the process number 9.277/16.

\section{Farm characterization, clinical signs, animal selection and treatment}

The Dairy farm used in this study was located in Mococa, São Paulo ( $21^{\circ} 28^{\prime} 04^{\prime \prime} \mathrm{S}$ and $\left.47^{\circ} 00^{\prime} 17^{\prime \prime} \mathrm{W}\right)$, with a total area of 100 hectares. The farm herd consisted of six horses and 608 Girolando and Gir dairy cattle, vaccinated against mastitis, leptospirosis and bovine respiratory disease, clostridiosis, brucellosis, rabies and foot-and-mouth disease. For the control of worms, in non-lactating animals, there is the frequent use of endectocides doramectin, ivermectin and levamisole cloridrate. Diptera and biting flies (Tabanus spp., Stomoxys calcitrans, and Haematobia irritans) control were frequently performed with fipronil and cypermethrin pour on. During the experimental period, animals presented low Stomoxys calcitrans infestation and the absence of Haematobia irritans and Tabanus spp. Oxytocin was administrated to all animals before milking, and sharing of syringes and needles was usual before $T$. vivax was diagnosed. After trypanosomosis diagnosis, in order to reduce $T$. vivax transmission, syringes and needles sharing was abolished, and one needle and syringe per animal was used. Every equipment contaminated with bovine blood was washed with running water and detergent, then stored in a solution with alkyl dimethyl benzyl ammonium chloride and polyoxyethylene nonylphenyl ether for two hours. After this, blood-contaminated equipment was immersed in hot water $\left(85^{\circ} \mathrm{C}\right)$ for 20 minutes and dried, reused in the next milking.

T. vivax could have been introduced into the farm through two cows borrowed from another dairy farm located in Rifaina, São Paulo ( $20^{\circ} 04^{\prime} 50^{\prime \prime} \mathrm{S}$ and $47^{\circ} 25^{\prime} 17^{\prime \prime} \mathrm{W}$ ), in early 2012, remaining there a year. Upon return, these 
cows presented low body score, hyporexia, cough, and nasal discharge. One of these cows died within the first days after return. Four months after returning these animals, other animals presented progressive weight loss, a sudden drop in milk production, abortion, cough, and death. No response to the antibiotic, anti-inflammatory, and supportive therapy was observed. Over time, the occurrence of sick animals decreased, with sporadic cases leading to deaths. However, surviving cattle did not recover their previous body score and did not return to their original milk production, always being below the herd average.

Given the above, the occurrence of bovine trypanosomosis was suspected. For the initial T. vivax diagnosis, whole blood samples were collected in tubes containing EDTA from animals with a history of clinical signs resembling trypanosomosis. A total of 13.6\% (83/608) cattle were sampled and submitted to the thick-drop test (Brener, 1961) and LAMP. Although all samples were negative for the parasitological test, $41.0 \%$ (34/83) were positive in the LAMP test. Among these, 30 samples (Bovine 1 to 30 ) were randomly selected to design the present study.

After diagnosis, all animals, including newborns and horses, were treated with $1.0 \mathrm{mg} / \mathrm{Kg}$ of isometamidium chloride (ISM; Vivedium ${ }^{\circledR}$, Sumaré, CEVA Saúde Animal S.A.) intramuscularly deep in the neck, on day 0 (D0). After 150 days from the first treatment (D150), all animals received another dosage. The 30 selected animals were followed by 240 days after treatment, and blood samples were collected from the external jugular vein on days $0,7,15,30,60,90,120,150,180,210$, and 240, using evacuated collection tubes with and without EDTA. Samples from D0 and D150 were collected immediately before ISM application. Blood and serum samples were aliquoted in triplicate and stored at $-80^{\circ} \mathrm{C}$ until required. During the experimental period, there was no outgoing or purchase of animals. Bovine number 10 died on day 136 due to acute bleeding from udder injury, and it was not possible to collect material from D150 onwards.

\section{Molecular assay}

EDTA-whole blood DNA extraction was performed based on the genomic DNA isolation protocol described by Kuramae-Izioka (1997). In order to avoid sample contamination, DNAse and RNAse free ultra-pure autoclaved water (Invitrogen ${ }^{\circledR}$, Carlsbad, USA), called extraction controls, was added in each extraction batch. Each DNA was subject to spectrophotometric analysis (Nanodrop 2000®, Thermo Scientific, USA), aiming at obtaining the measurement of concentrations and 260/280 and 260/230 ratios. All samples and extraction controls were subjected to PCR for the endogenous gene GAPDH, as described by Birkenheuer et al. (2003), using GAPDH F (5' CCTTCATTGACCTCAACTACAT3') and GAPDH R (5'CCAAAGTTGTCATGGATGACC3') primers.

PCR for T. vivax was performed using a set of primers based on the DNA sequence of the $T$. vivax CatL gene, as previously described by Cortez et al. (2009), using the primers (TviCatL [5' GCCATCGCCAAGTACCTCGCCGA3'] and DT0155 [5' TTAAAGCTTCCACGAGTTCTTGATGATCCAGTA3'], IDT®, USA), that flank a fragment of 177 base pairs of the CatL-Like catalytic domain region gene, which encodes the $T$. vivax Cathepsin L-like (CatL) enzyme. T. vivax strain Lins (Cadioli et al., 2012) DNA was used as a positive control.

All animals on D0 and samples that presented Absorbance $(A)$ above 0.400 in ELISA were submitted to an additional PCR assay for T. theileri, according to the methodology described by Rodrigues et al. (2010), using TthCatL1 (5 'CGTCTCTGGCTCCGGTCAAAC3 ') and DTO155 (5'TTAAAGCTTCCACGAGTTCTTGATGATCCAGTA3') primers. In vitro cultivated $T$. theileri sample was used as the positive control, and sterilized ultra-pure water (Invitrogen ${ }^{\circledR}$, Carlsbad, USA) was used as a negative control in all PCR assays.

All PCR assays were conducted in T100 TM Thermal Cycler (Bio-Rad, USA), and products were analyzed on 2\% agarose gel containing ethidium bromide. The gel image was obtained using the ChemiDoc ${ }^{\mathrm{TM}} \mathrm{MP}$ imaging system (Bio-Rad) with 100 bp size DNA standards (GeneRuler 50 bp DNA Ladder; Thermo Fisher Scientific; Waltham, MA, USA).

For the LAMP technique, a set of primers flanking a 125 base pairs fragment of the $T$. vivax satellite DNA sequence (GenBank: J03989), as described by Njiru et al. (2011), was used. Primers used were outer primers F3 (5'TGTTCTGGTGGCCTGTTGC3') and B3 (5'GGCCGGAGCGAGAGGTGC3'), internal primers FIP (5'GTGGAGCGTGCCAACGTGGACCCGCTCCCAGACCATA3') and BIP (5'TGTCTAGCGTGACGCGATGGAAGAGGGAGTGGGGAAGG3'), and loop primers LF (5' CACATGGAGCATCAGGAC3') and LB (5' CCGTGCACTGTCCCGCAC3'). All reactions were performed in triplicate, accompanied by sterilized ultra-pure water (Invitrogen ${ }^{\circledR}$, Carlsbad, USA) as negative control and T. vivax Lins strain DNA (Cadioli et al., 2012; Garcia et al., 2014) as a positive control. Reactions were conducted in CFX96 thermocycler (BioRad, USA) at $63^{\circ} \mathrm{C}$ for 60 mins, resulting in 60 cycles. After raising the temperature to $80^{\circ} \mathrm{C} / 5 \mathrm{~min}$., the melting curves were acquired using $0.5^{\circ} \mathrm{C} / 5 \mathrm{~s}$ increases for each step from 63 to $96^{\circ} \mathrm{C}$, to confirm the specificity of the amplicons for 
T. vivax. Results were read through observation of amplification curves using the Bio-Rad CFX Manager software, in which the Cq (cycle threshold) of each sample was annotated.

\section{Serological assay}

The ELISA was carried out as previously described by Machado et al. (1997) and Aquino et al. (1999), with minor modifications as described below. Each microplate well (Nunc MaxiSorp ${ }^{\circledR}$, Thermo Fischer Scientific, Massachusetts, USA) was coated with $100 \mu \mathrm{L}$ of $T$. vivax soluble antigen at a concentration $0.1 \mu \mathrm{g} / \mathrm{mL}$. All tested samples and positive and negative controls were diluted 1:50 in phosphate-buffered saline with Tween-20 ([PBST]; $130 \mathrm{mM} \mathrm{NaCl}, 2.7 \mathrm{mM} \mathrm{KCl}, 5.6 \mathrm{mM} \mathrm{Na}_{2} \mathrm{HPO}_{4}, 1 \mathrm{mM} \mathrm{KH}_{2} \mathrm{PO}_{4}, 0.92 \mathrm{mM} \mathrm{NaH}_{2} \mathrm{PO}_{4}$ and $0.05 \%$ Tween 20). All sera were tested in duplicate. The reaction was read by a microplate reader (MRX TC Plus, Dynex Technology, USA) at $405 \mathrm{~nm}$. The blank well did not contain serum.

To define the cutoff between plates, two negative controls and one positive control were used in all test plates. Negative controls sera were obtained from two cows from a herd located in a T. vivax non-endemic region and previously tested using molecular (PCR and LAMP) and serological (ELISA) tests. The positive control was a bovine experimentally infected with T. vivax "Lins" isolate (Fidelis et al., 2016). The mean and standard deviation (SD) of the $A$ from negative controls of all plates were then obtained, and the cutoff was calculated according to the following equation, described by Madruga et al. (2006):

Cutoff $=$ negative controls mean $+(3 \times$ Negative Controls SD $)$

\section{Statistical analysis}

The Kappa concordance test was performed between PCR, LAMP and ELISA. The test was interpreted according to Landis \& Koch (1977), in which Kappa $<0.00=$ poor agreement; 0.00 to $0.20=$ slight agreement; 0.21 to $0.40=$ reasonable agreement; 0.41 to $0.60=$ moderate agreement; 0.61 to $0.80=$ substantial agreement; 0.81 to $1.00=$ almost perfect agreement. BioEstat software version 5.0 was used for this purpose.

\section{Results and Discussion}

This study is the first to use LAMP as a diagnostic tool for the follow-up of T. vivax in naturally infected cattle after trypanocidal drug treatment. Also, it is the first experiment in Brazil to follow-up T. vivax naturally infected cattle after treatment with ISM and is a pioneer in investigating cross-reactivity by $T$. vivax and $T$. theileri in a naturally infected herd.

\section{Molecular methods}

During the experimental period, 326 EDTA-blood samples were collected. The mean and standard error (SE) of the DNA concentration, 260/230, and 260/280 ratios were $97.4 \pm 4.83 \mathrm{ng} / \mu \mathrm{L}, 0.72 \pm 0.02$, and $1.57 \pm 0.03$, respectively. All samples were positive for the GAPDH gene, except for the extraction controls.

Trypanosoma vivax PCR presented five-time points of positivity, four after the first (D60, D90, D120, and D150) and one after the second (D210) ISM administration (Figure 1). All extraction controls were negative in the PCR for T. vivax, excluding cross-contamination during the DNA extraction procedure. Overall, PCR detected $T$. vivax DNA in only 1.8\% (6/326) of samples between D0 to D240; however, in the posttreatment period (D7 to D240) PCR detected 2.0\% (6/296) of positivity samples which were bovines 1 (D90), 8 (D210), 11 (D210), 20 (D120) and 5 (D60 and D150).

On the other hand, LAMP detected T. vivax DNA at all times, with global detection of $25.8 \%$ (84/326). Extraction controls were negative in all batches. In the posttreatment period (D7 to D240), LAMP detected the presence of $T$. vivax DNA in 18.2\% (54/296) of the samples. Higher positivity was observed on D7 (9/30) and D120 (9/30). A lower positivity was observed on D60 (2/30) and D210 (2/29), 60 days after the first and second ISM applications, respectively (Table 1). The individual analysis showed fluctuation in the positivity for all animals, except bovines 7 , $14,15,18,23,28$, and 30, which remain negative after the first ISM treatment.

The mean and SE of the Cq of positive samples in LAMP were $39.8 \pm 1.12 \mathrm{Cq}$, which characterizes samples with a low amount of $T$. vivax DNA. The DNA positive control presented an average and SE Cq of $15.4 \pm 0.32$. Considering 


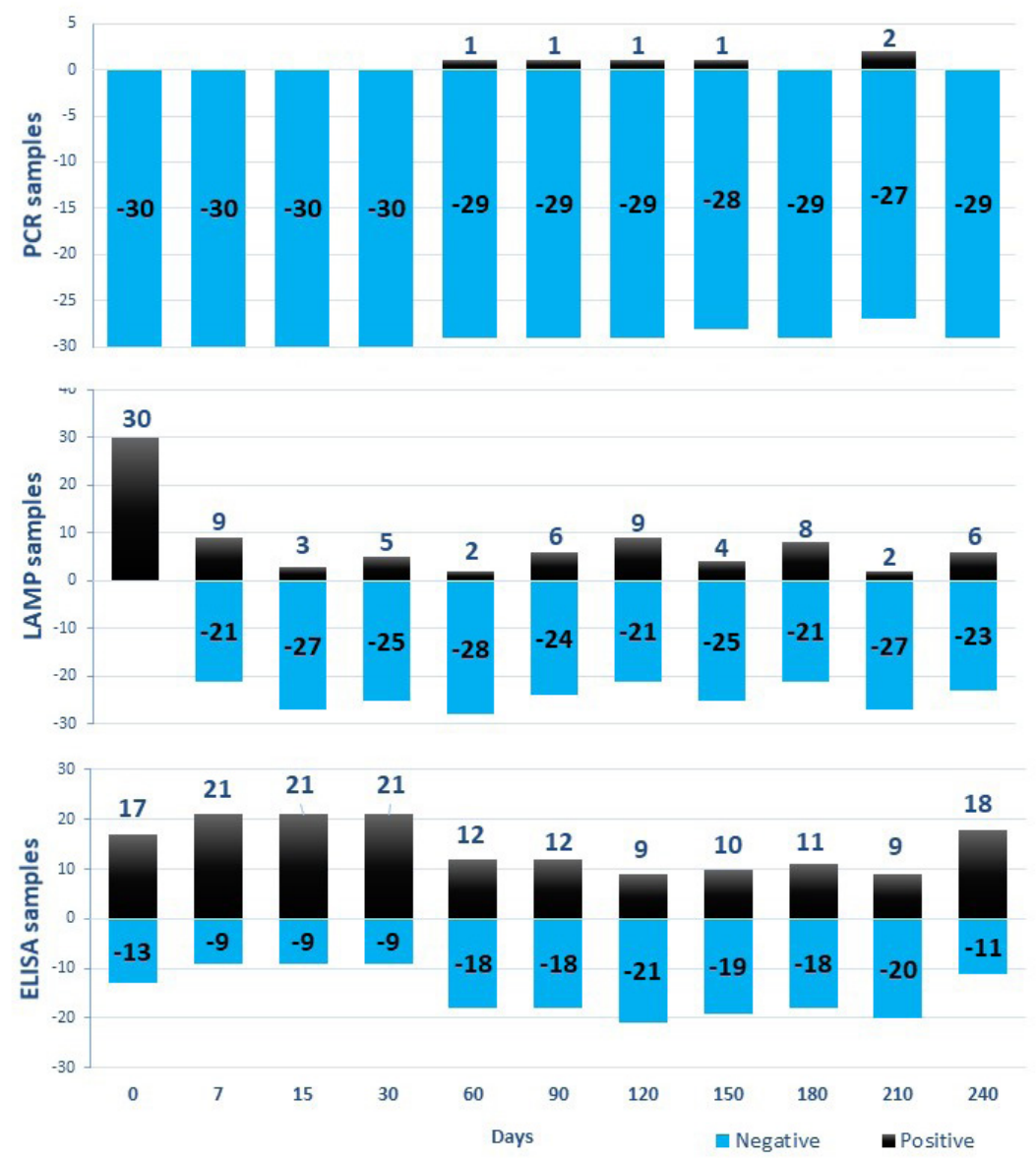

Figure 1. Trypanosoma vivax detection by PCR, LAMP, and ELISA techniques in blood or serum samples from naturally infected cattle before and after isometamidium chloride hydrochloride treatment (1 mg/Kg) at D0 e D150.

that the melting temperature specific for $T$. vivax DNA was $87.5^{\circ} \mathrm{C}$, samples presenting melting temperatures between 87.0 and $88.0^{\circ} \mathrm{C}$ were considered positive.

LAMP is an available tool for diagnosing several pathogens, and it is increasingly used for humans (Grab et al., 2011) and animal trypanosomosis diagnosis (Haji et al., 2015). LAMP results revealed that all selected time points presented animals keeping T. vivax DNA after treatment. No difference between the number of positivity and days after the first (D7 to D150) or second ISM application (D180 to D240) was found.

Throughout the experimental period, except for D210, LAMP presented higher detection capacity when compared to PCR. Increased diagnostic capacity for Trypanosoma DNA detection was also observed by other authors when LAMP was employed (Cadioli et al., 2015; Laohasinnarong et al., 2015). The higher diagnostic capability of LAMP is because this technique has a detection threshold of $1 \mathrm{pg}$ of DNA, which corresponds to 1 trypanosome/mL of blood (Njiru et al., 2011).

The use of PCR resulted in misdiagnosis in every analyzed time point, except for D210, in which the two animals detected by PCR were also positive in LAMP. Heparin, free hemoglobin, myoglobin, antibodies, and fecal contamination may inhibit PCR by inactivating Taq DNA polymerase (Kuboki et al., 2003; Grab et al., 2005; Schrader et al., 2012), which is less likely to occur in LAMP (Kaneko et al., 2007; Nimitphak et al., 2008), as the later uses Bst DNA polymerase. Herein, the presence of PCR inhibitors was discarded once all samples tested were positive for the GAPDH gene, thus ensuring the samples' quality and the integrity of the extracted DNA. Fidelis et al. (2019) showed that PCR and real-time PCR had the same detection rates for T. vivax; instead, QPCR is useful to determine parasitic load but much more expensive than conventional PCR.

Low concentrations of T. vivax DNA related to low parasitemia may also affect the PCR outcomes (Morlais et al., 2001; Cadioli et al., 2015, Fidelis et al., 2019). In the present study, LAMP positive samples presented high mean 
Table 1. DNA detection dynamics of Trypanosoma vivax by LAMP in animals that presented detectable DNA fluctuations after treatment with isometamidium hydrochloride at a dose of $1 \mathrm{mg} / \mathrm{kg}$ in D0 and D150.

\begin{tabular}{|c|c|c|c|c|c|c|c|c|c|c|c|}
\hline Animal & Do & D7 & D15 & D30 & D60 & D90 & D120 & D150 & D180 & D210 & D240 \\
\hline Bovine 1 & + & - & - & + & - & + & + & - & - & - & + \\
\hline Bovine 2 & + & + & - & - & - & - & - & - & + & - & + \\
\hline Bovine 3 & + & + & - & + & - & - & - & - & - & - & - \\
\hline Bovine 4 & + & - & - & - & - & - & - & - & - & - & + \\
\hline Bovine 5 & + & + & - & - & + & + & - & + & + & - & - \\
\hline Bovine 6 & + & - & - & - & - & - & + & - & - & - & - \\
\hline Bovine 8 & + & + & - & - & - & - & - & + & - & + & - \\
\hline Bovine 9 & + & - & - & - & - & - & - & - & + & - & - \\
\hline Bovine 10 & + & + & - & - & - & + & - & $x$ & $x$ & $x$ & $x$ \\
\hline Bovine 11 & + & - & - & - & - & - & - & - & + & + & - \\
\hline Bovine 12 & + & - & - & - & - & - & + & - & - & - & + \\
\hline Bovine 13 & + & - & - & - & - & - & - & + & - & - & - \\
\hline Bovine 16 & + & + & - & - & + & - & - & - & - & - & - \\
\hline Bovine 17 & + & - & - & - & - & + & + & - & + & - & - \\
\hline Bovine 19 & + & - & - & + & - & - & - & - & + & - & - \\
\hline Bovine 20 & + & - & - & + & - & + & + & - & + & - & - \\
\hline Bovine 21 & + & - & - & + & - & - & + & - & - & - & - \\
\hline Bovine 22 & + & - & - & - & - & - & + & - & - & - & - \\
\hline Bovine 24 & + & + & - & - & - & - & - & - & + & - & - \\
\hline Bovine 25 & + & - & + & - & - & - & + & - & - & - & - \\
\hline Bovine 26 & + & - & - & - & - & + & - & + & - & - & + \\
\hline Bovine 27 & + & + & + & - & - & - & + & - & - & - & + \\
\hline Bovine 29 & + & - & + & - & - & - & - & - & - & - & - \\
\hline
\end{tabular}

+ (Positive); - (Negative); x (lost sample).

Cq (39.4), which indicates that positive animals experienced low $T$. vivax parasitemias after treatment, thus justifying PCR failure. Studies previously performed by Cadioli et al. (2015) and Fidelis et al. (2019) showed that in the chronic/sub-patent phase of infection, T. vivax tends to present very low parasitemia, which difficult disease diagnosis in herds.

Thus, LAMP has proved to be a handy tool in monitoring T. vivax clearance by infected animals, identifying positive animals over time, and proving a sensitive diagnostic test. The same cannot be stated for PCR, which was not able to detect a large number of positive samples, even before treatment (D0). This failure may induce errors in the herd treatment, since it is assumed that treatment was effective, when, in fact, the technique sensitivity is low. Thus, PCR contributes to the maintenance of "apparently" cured animals in the herds, which keeps the parasite on the farm and also promote its spread through commercial routes, being considered the primary way of parasite dispersal (Silva et al., 1998; Jones \& Dávila, 2001).

Fluctuations in T. vivax DNA detection were observed during the experimental period, which might be explained by the parasite's transient elimination, which corroborates previous observations described by other authors after ISM treatment, either by using parasitological (Dagnachew et al., 2015) or molecular diagnostic techniques (Vitouley et al., 2012). Alternatively, the amount of T. vivax DNA might have been below the limit of detection. The occurrence of animals presenting T. vivax recirculation after ISM treatment is essential information for disease 
control, which can be considered as a persistent infection. In fact, if new infections by another T. vivax strain had occurred, positive animals in serological and molecular tests will have increased, a fact not observed in this experiment. Therefore, these observations indicate that ISM is not capable of eliminating T. vivax in few doses and longtime treatment will be necessary, just like keep constant herd monitoring, thus avoiding reinfections that could generate substantial impacts by treatment failure.

\section{Serological assay}

The mean and SD (SE) of $A$ from the negative controls were $0.117 \pm 0.031(0.009)$, and the cutoff value was 0.209. Positive control presented mean and SD (SE) of $1.079 A \pm 0.148(0.060)$, respectively. Overall, ELISA detected $49.4 \%$ (161/326) of seropositive samples for T. vivax. It was also observed that $48.7 \%(144 / 296)$ of the samples were seropositive for $T$. vivax after treatment (D7 to D240).

Although the presence of seropositive animals was detected in all moments after treatment, it is possible to observe that after the first ISM application, there was a decrease in the number of seropositive animals, with the smaller number on D120 (Figure 1). It is also noted a reduction in the average values of $A$, being close to the cutoff, and reaching lower values on D60 and D150 (Figure 2). However, the second application ISM (D150), did not affect the number of seropositive animals. Indeed, an increase in $A$ values was observed on the last day (D240) (Figures 1 and 2).

The lack of detectable IgG antibodies in positive animals (D0) occurred in five moments, namely D7, D15, D60, D120, and D180. Bovine one became seronegative on D7; bovine three on D15; bovines 7, 11, 17, 22, and 27 on D60; bovines 5, 20 and 21 on D120 and finally bovine 18 on D180. Diagnostic fluctuations during the experimental period was observed in bovines 1, 2, 3, 4, 5, 6, 7, 8, 11, 14, 15, 18, 19, 20, 21, 24 and 26 (Table 2). After becoming seronegative on D60, bovines 17, 22 and 27, remained so until the last evaluation. Bovines 10, 12, 16, 25,29 , and 30 remained seropositive in the entire period, and bovines 9, 13, 23, and 28 remained seronegative throughout the experimental period.

ELISA is a widely used technique for seroepidemiological studies for T. vivax in Africa (Dagnachew \& Bezie, 2015) and South America (Osório et al., 2008; Sampaio et al., 2015), providing valuable information about herd status. In the present study, although this method diagnosed only 17 out of 30 animals considered positive by LAMP on DO (Figure 1), this serological assay showed a high capacity to detect positive animals in the posttreatment period.

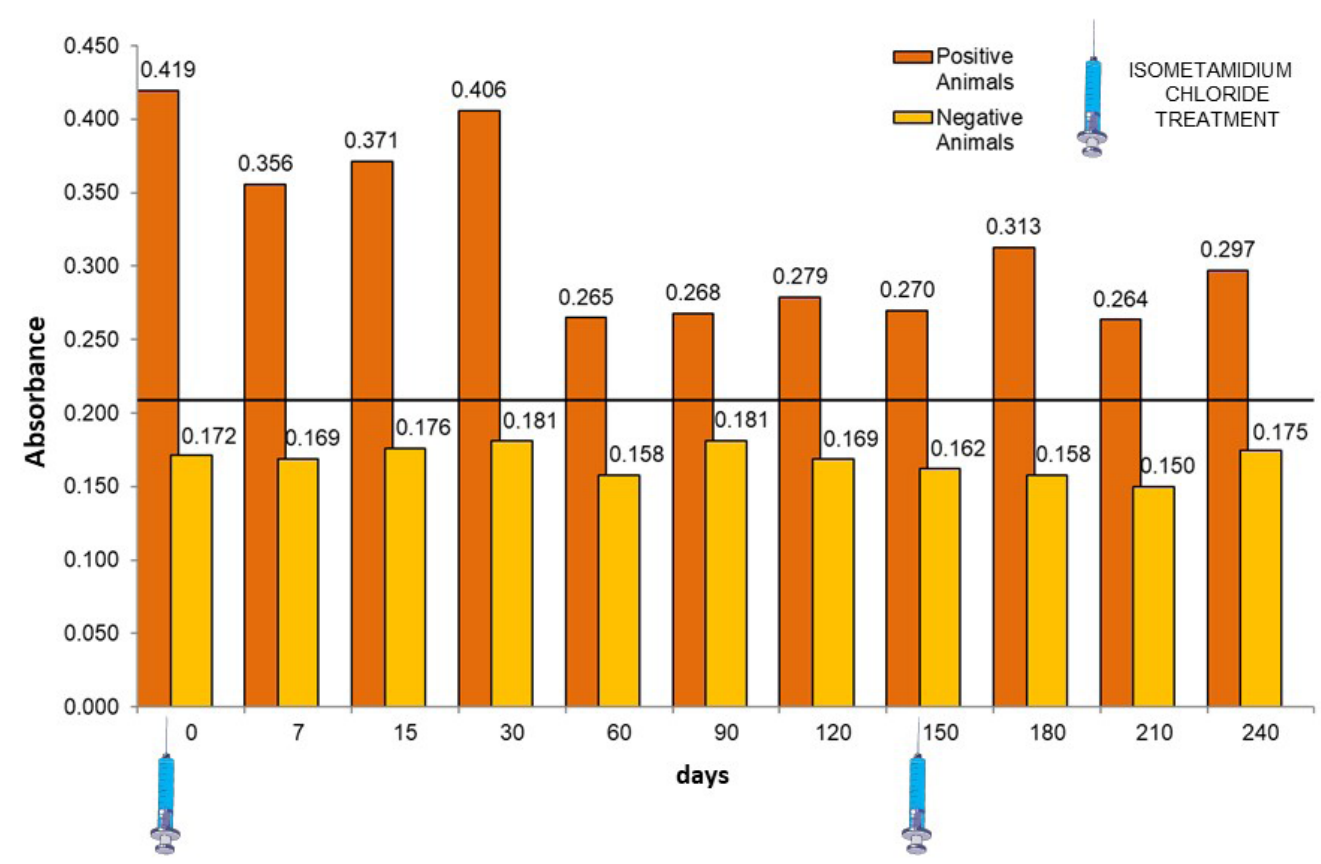

Figure 2. Anti-Trypanosoma vivax IgG antibodies Absorbance $(A)$ in each selected time point of T.vivax-naturally infected cattle serum samples before and after isometamidium chloride hydrochloride treatment (1 mg/Kg) at D0 e D150. 
Table 2. Dynamics of detection of anti-Trypanosoma vivax antibodies by ELISA in animals that presented diagnostic fluctuations after treatment with isometamidium hydrochloride at a dose of $1 \mathrm{mg} / \mathrm{kg}$ in D0 and D150.

\begin{tabular}{|c|c|c|c|c|c|c|c|c|c|c|c|}
\hline Animal & Do & D7 & D15 & D30 & D60 & D90 & D120 & D150 & D180 & D210 & D240 \\
\hline Bovine 1 & + & - & - & - & - & - & - & - & - & - & + \\
\hline Bovine 2 & - & + & + & + & + & - & - & - & - & - & - \\
\hline Bovine 3 & + & + & - & - & - & - & - & + & + & + & + \\
\hline Bovine 4 & - & + & + & + & - & - & - & - & - & - & - \\
\hline Bovine 5 & + & + & + & + & + & + & - & - & - & - & + \\
\hline Bovine 6 & - & - & - & - & - & + & + & + & + & + & + \\
\hline Bovine 7 & + & + & + & + & - & - & + & - & + & - & + \\
\hline Bovine 8 & - & - & - & - & - & - & - & - & + & - & + \\
\hline Bovine 11 & + & + & + & + & - & - & - & + & + & - & + \\
\hline Bovine 14 & - & + & + & + & - & - & - & - & - & - & + \\
\hline Bovine 15 & - & + & + & + & - & - & - & - & - & - & - \\
\hline Bovine 18 & + & + & + & + & + & + & + & + & - & - & + \\
\hline Bovine 19 & - & - & + & + & - & - & - & - & - & - & + \\
\hline Bovine 20 & + & + & + & + & + & + & - & - & - & - & + \\
\hline Bovine 21 & + & + & + & + & + & + & - & - & - & + & + \\
\hline Bovine 24 & - & - & - & - & + & + & - & - & - & - & - \\
\hline Bovine 26 & - & + & + & + & - & - & - & + & + & + & + \\
\hline
\end{tabular}

+ (Positive); - (Negative).

According to Nantulya (1990), ELISA is highly sensitive for T. vivax diagnosis, but there are reports of unsatisfactory results, showing lower sensitivity when compared to PCR (Desquesnes, 1997) and LAMP (Cadioli et al., 2015).

Over time, antibody levels tend to decrease progressively after treatment. Desquesnes et al. (2003) and Monzon et al. (2003), using T. vivax and T. evansi total soluble crude antigens, observed that decrease occurs from 2 and 2.3 months in cattle and horses naturally infected by $T$. vivax and T. evansi after treatment with DA and quinapyramine sulfate, respectively. In the present study, six animals remained seropositive until the end of the experimental period, and for those that became seronegative, this occurred 60 days after the first application of ISM. This antibody behavior was also observed in cattle experimentally infected by $T$. vivax (Desquesnes et al., 2003; Pillay et al., 2013). Pillay et al. (2013), using T. vivax recombinant GM6 antigen, noted that most animals became seronegative 30 days after DA treatment. On the other hand, Desquesnes et al. (2003), using T. vivax total soluble crude antigen, found a higher number of seronegative animals 90 days after DA treatment.

On D7 was a striking reduction in LAMP detection, but by ELISA, the seropositivity and the average $A$ decay occurred from D60 (Figures 1 and 2). A similar trend was observed by Bengaly et al. (2001) using molecular (PCR) and serological (ELISA) diagnostic methods to evaluate the therapeutic efficacy of DA in sheep experimentally infected by $T$. vivax and T. congolense. In that experiment, negativity by PCR was observed one to two days after treatment, much earlier than 60 to 100 days observed by ELISA. This late trend of antibody reduction after treatment showed by ELISA indicates that this method should be evaluated for a long time or interpreted in conjunction with molecular techniques, thus avoiding errors in assessing the actual herd infection situation.

ELISA techniques are designed to detect antibodies against Trypanosoma spp. These techniques are often performed using a soluble crude lysate of trypanosome antigens, which makes ELISA a problematic test to standardize and with the possibility of presenting cross-reactions with other trypanosome species, including T. theileri (Luckins, 1977; Desquesnes et al., 2001; Jones \& Dávila, 2001). Trypanosoma theileri is a cosmopolitan parasite that, if not associated with other concomitant infections or stressful conditions, is not pathogenic to cattle and buffaloes. This species of Trypanosoma has already been detected in healthy cattle in São Paulo, Brazil (Rodrigues et al., 2003). 
In order to rule out the occurrence of $T$. theileri among animals from the present study and the possibility of serological cross-reaction in the used ELISA, a PCR specific for this parasite was performed in 56 selected samples from all animals on D0 (30 samples) and 26 samples that presented ELISA $A$ above 0.400 . All tested samples were negative, thus ruling out the occurrence of serological cross-reaction in the ELISA.

While Kappa results between LAMP and PCR (0.10) and LAMP and ELISA (0.02) indicate slight agreement, it showed a poor agreement (-0.02) between PCR and ELISA. These results agree with those obtained by Fidelis et al. (2019), which evaluated different techniques for disease diagnoses, obtaining a Kappa index of 0.07 between PCR and ELISA. The low Kappa values observed in the present study represent a reflection of the different detection rates obtained, which are inherent to different detection targets of each technique. This finding reinforces the need for a combination of serological and molecular assays to diagnose naturally infected $T$. vivax herds, an observation already pointed out by Fidelis et al. (2019).

In Africa, T. vivax recirculation in cattle treated with ISM has been reported with increasing frequency (Dagnachew \& Bezie, 2015) and have been associated with the long-term use of the drugs, underdosing, and formulations with inadequate chemotherapy concentrations (Dagnachew et al., 2015; Tekle et al., 2018). Moreover, parasite recirculation after treatment was correlated with the presence of $T$. vivax in refuge sites, such as cerebrospinal fluid, choroid plexus, and aqueous humor (Whitelaw et al., 1988; Batista et al., 2011), in which the drug does not reach adequate concentrations even during the prophylaxis period (Giordani et al., 2016), which could be up to 160 days for $1 \mathrm{mg} / \mathrm{kg}$ of ISM (Toro et al., 1983). Therefore, it can be hypothesized that the persistence of $T$. vivax DNA showed by the used molecular methods could be due to parasites leaving their refuge sites and returning to the bloodstream.

On the other hand, ELISA results showed seropositivity at all selected time points, with the lowest percentage of detection represented by 30\% (9/30) of sampling (Figure 1) and the presence of 6 animals seropositive at all times, even after the second ISM dose. These findings indicate the occurrence of $T$. vivax antigens stimuli, possibly coming from the selection of parasites by the treatment, which may have culminated with the maintenance of animal infection.

Trypanocidal drug resistance testing can be performed by in vivo, in vitro, or by molecular methods. In vivo tests, such as the use of cattle in herds, is a method that does not require parasite isolation and is proposed to evaluate probable resistance in the field directly, and results are only indicative of resistance (Giordani et al., 2016). However, in the field, reinfection of animals after treatment, especially in areas with high exposure to mechanical or biological vectors, may interfere with the obtained results, mainly when drugs without prophylactic effect are used (Moti et al., 2015).

After T. vivax diagnostic, preventive measures were implemented in the farm to avoid the introduction of new animals in the herd, control of hematophagous flies and, treatment of all herd with ISM, including horses. Fomites as blood-contaminated needles, syringes, palpation gloves and, identification equipment were disinfected as previously commented.

Fomites control, a low infestation of blood-sucking flies, herd isolation in association with very low or apasitemic positive bovines reduces the probability of transmission between animals in the herd, so T. vivax detection during the experimental period allows us to state that there was no reinfection; however, the animals remain persistently infected by T. vivax. Considering persistent infection status as a critical problem in infected herds, treatments in intervals of 150 days may not be adequate because a raise of positive samples were detected by LAMP as observed; thus, shorten treatment intervals as 120 days must be considered.

Another relevant information related to the persistent infection observed is the possible induction of ISM resistance, which is a disturbing fact, as it may imply in treatment failure of herds when ISM is used.

\section{Conclusions}

As far we know, this is the first experiment that demonstrates the persistence infection of $T$. vivax under ISM treatment in a natural infected herd and evidence of ISM chemotherapy-resistant T. vivax in Brazil. The combination of both LAMP and ELISA proved to be very useful for achieving the diagnosis and monitoring of cattle naturally infected by $T$. vivax before and after treatment with ISM. On the other hand, PCR is not indicated for T. vivax diagnosis in cattle as a single diagnostic tool. We observed that the prophylactic dose of ISM does not eliminate T. vivax and treatment intervals as 120 days must be considered, an essential data of future strategies to tackle bovine trypanosomosis in Brazilian herds. 


\section{Acknowledgements}

We thank São Paulo Research Foundation (FAPESP) for financial support in the form of grant given through procedural number 2015/25397-6, as well as CEVA Saúde Animal SA, for Vivedium ${ }^{\circledR}$ supply used in this study. MRA is a fellowship researcher of "Conselho Nacional de Desenvolvimento Científico e Tecnólogico" (Bolsa de Produtividade - CNPq Process number \#302420/2017-7).

\section{References}

Aquino LP, Machado RZ, Alessi AC, Marques LC, de Castro MB, Malheiros EB. Clinical, parasitological and immunological aspects of experimental infection with Trypanosoma evansi in dogs. Mem Inst Oswaldo Cruz 1999; 94(2): 255-260. http://dx.doi.org/10.1590/ S0074-02761999000200025. PMid:10224539.

Bastos TSA, Faria AM, de Assis Cavalcante AS, de Carvalho Madrid DM, Zapa DMB, Nicaretta JE, et al. Comparison of therapeutic efficacy of different drugs against Trypanosoma vivax on experimentally infected cattle. Prev Vet Med 2020; 181: 105040. http:// dx.doi.org/10.1016/j.prevetmed.2020.105040. PMid:32516747.

Bastos TSA, Faria AM, Madrid DMC, Bessa LC, Linhares GFC, Fidelis OLJr, et al. First outbreak and subsequent cases of Trypanosoma vivax in the state of Goiás, Brazil. Rev Bras Parasitol Vet 2017; 26(3): 366-371. http://dx.doi.org/10.1590/s1984-29612017019. PMid:28678894.

Batista JS, Rodrigues CMF, García HA, Bezerra FSB, Olinda RG, Teixeira MMG, et al. Association of Trypanosoma vivax in extracelular sites with central nervous system lesions and changes in cerebrospinal fluid in experimentally infected goats. Vet Res (Faisalabad) 2011; 42(1): 63. http://dx.doi.org/10.1186/1297-9716-42-63. PMid:21569364.

Bengaly Z, Kasbari M, Desquesnes M, Sidibé I. Validation of a polymerase chain reaction assay for monitoring the therapeutic efficacy of diminazene aceturate in trypanosome-infected sheep. Vet Parasitol 2001; 96(2): 101-113. http://dx.doi.org/10.1016/ S0304-4017(00)00426-X. PMid:11230917.

Birkenheuer AJ, Levy MG, Breitschwerdt EB. Development and evaluation of a semi-nested PCR for detection and differentiation of Babesia gibsoni (Asian genotype) and B. canis DNA in canine blood samples. J Clin Microbiol 2003; 41(9): 4172-4177. http:// dx.doi.org/10.1128/JCM.41.9.4172-4177.2003. PMid:12958243.

Brener Z. Contribuição ao estudo da terapêutica experimental da doença de Chagas [tese]. Belo Horizonte: Universidade Federal de Minas Gerais; 1961.

Cadioli FA, Barnabé PA, Machado RZ, Teixeira MC, André MR, Sampaio PH, et al. First report of Trypanosoma vivax outbreak in dairy cattle in São Paulo state, Brazil. Rev Bras Parasitol Vet 2012; 21(2): 118-124. http://dx.doi.org/10.1590/S1984-29612012000200009. PMid:22832751.

Cadioli FA, Fidelis OL Jr, Sampaio PH, Santos GN, André MR, Castilho KJGA, et al. Detection of Trypanossoma vivax usind PCR and LAMP during aparasitemic periods. Vet Parasitol 2015; 214(1-2): 174-177. http://dx.doi.org/10.1016/j.vetpar.2015.09.001. PMid:26414906.

Cortez AP, Rodrigues AC, Garcia AH, Neves L, Batista JS, Bengaly Z, et al. Cathepsin L-like genes of Trypanosoma vivax from Africa and South America - characterization, relationships and diagnostic implications. Mol Cell Probes 2009; 23(1): 44-51. http://dx.doi. org/10.1016/j.mcp.2008.11.003. PMid:19063960.

Cuglovici DA, Bartholomeu DC, Reis-Cunha JL, Carvalho AU, Ribeiro MFB. Epidemiologic aspects of an outbreak of Trypanosoma vivax in a dairy cattle herd in Minas Gerais state, Brazil. Vet Parasitol 2010; 169(3-4): 320-326. http://dx.doi.org/10.1016/j. vetpar.2009.12.041. PMid:20138431.

Dagnachew S, Bezie M. Review on Trypanosoma vivax. Afr J Basic App/ Sci 2015; 7(1): 41-64. http://dx.doi.org/10.5829/idosi. ajbas.2015.7.1.92116.

Dagnachew S, Terefe G, Abebe G, Barry D, McCulloch R, Goddeeris B. In vivo experimental drug resistance study in Trypanosoma vivax isolates from tsetse infested and non-tsetse infested areas of Northwest Ethiopia. Acta Trop 2015; 146: 95-100. http://dx.doi. org/10.1016/j.actatropica.2015.03.014. PMid:25792418.

Dávila AMR, Herrera HM, Schlebinger T, Souza SS, Traub-Cseko YM. Using PCR for unraveling the cryptic epizootiology of livestock trypanosomosis in the Pantanal, Brazil. Vet Parasitol 2003; 117(1-2): 1-13. http://dx.doi.org/10.1016/j.vetpar.2003.08.002. PMid:14597273.

Desquesnes M, Bengaly Z, Dia ML. Evaluation de la persistance des anticorps détectés par Elisa-indirect Trypanosoma vivax après traitement trypanocide chez des bovins natturellement infectés. Revue Élev Vét Pays Trop 2003; 56(3-4): 141-144. http://dx.doi. org/10.19182/remvt.9855. 
Desquesnes M, Bengaly Z, Millogo L, Meme Y, Sakande $\mathrm{H}$. The analysis of the cross-reactions occurring in antibody-ELISA for the detection of trypanosomes can improve identification of the parasite species involved. Ann Trop Med Parasitol 2001; 95(2): 141-155. http://dx.doi.org/10.1080/00034983.2001.11813624. PMid:11299121.

Desquesnes M, de La Rocque S, Peregrine AS. French Guyanan stock of Trypanosoma vivax resistant to diminazene aceturate but sensitive to isometamidium chloride. Acta Trop 1995; 60(2): 133-136. http://dx.doi.org/10.1016/0001-706X(95)00117-W. PMid:8610541.

Desquesnes M. Evaluation of simple PCR technique for the diagnosis of Trypanosoma vivax infection in the serum of cattle in comparison to parasitological techniques and antigen-enzyme- linked immunosorbent assay. Acta Trop 1997; 65(3): 139-148. http://dx.doi.org/10.1016/S0001-706X(96)00643-2. PMid:9177575.

Fidelis OL Jr, Sampaio PH, Gonçalves LR, André MR, Machado RZ, Wijffels J, et al. Comparison of conventional and molecular techniques for Trypanosoma vivax diagnosis in experimentally infected cattle. Rev Bras Parasito/ Vet 2019; 28(2): 203-209. http:// dx.doi.org/10.1590/s1984-29612019034. PMid:31188948.

Fidelis OL Jr, Sampaio PH, Machado RZ, André MR, Marques LC, Cadioli FA. Evaluation of clinical signs, parasitemia, hematologic and biochemical changes in cattle experimentally infected with Trypanosoma vivax. Rev Bras Parasitol Vet 2016; 25(1): 69-81. http://dx.doi.org/10.1590/S1984-29612016013. PMid:27007249.

Garcia HA, Rodrigues AC, Rodrigues CM, Bengaly Z, Minervino AH, Riet-Correa F, et al. Microsatellite analysis supports clonal propagation and reduced divergence of Trypanosoma vivax from asymptomatic to fatally infected livestock in South America compared to West Africa. Parasit Vectors 2014; 7(210): 1-13. http://dx.doi.org/10.1186/1756-3305-7-210. PMid:24885708.

Giordani F, Morrison LJ, Rowan TG, De Koning HP, Barrett MP. The animal trypanosomiases and their chemotherapy: a review. Parasitology 2016; 143(14): 1862-1889. http://dx.doi.org/10.1017/S0031182016001268. PMid:27719692.

Grab DJ, Lonsdale-Eccles J, Inoue N. Lamp for tadpoles. Nat Methods 2005; 2(9): 635-636, author reply 635-636. http://dx.doi. org/10.1038/nmeth0905-635a. PMid:16118631.

Grab DJ, Nikolskaia OV, Inoue N, Thekisoe OM, Morrison LJ, Gibson W, et al. Using detergent to enhance the detection sensitivity of African trypanosomes in human CSF and blood by Loop-mediated Isothermal Amplification (LAMP). PLoS Neg/ Trop Dis 2011; 5(8): e1249. http://dx.doi.org/10.1371/journal.pntd.0001249. PMid:21829738.

Haji IJ, Sugimoto C, Kajino K, Malele I, Simukoko H, Chitambo H, et al. Determination of the prevalence of trypanosome species in cattle from Monduli district, northern Tanzania, by loop-mediated isothermal amplification. Trop Anim Health Prod 2015; 47(6): 1139-1143. http://dx.doi.org/10.1007/s11250-015-0840-5. PMid:25953023.

Jones TW, Dávila AM. Trypanosoma vivax out of Africa. Trends Parasitol 2001; 17(2): 99-101. http://dx.doi.org/10.1016/S14714922(00)01777-3. PMid:11228017.

Kaneko H, Kawana T, Fukushima E, Suzutani T. Tolerance of loop-mediated isothermal amplification to a culture medium and biological substances. J Biochem Biophys Methods 2007; 70(3): 499-501. http://dx.doi.org/10.1016/j.jbbm.2006.08.008. PMid:17011631.

Kuboki N, Inoue N, Sakurai T, Di Cello F, Grab DJ, Suzuki H, et al. Loop-mediated isothermal amplification for detection of African trypanosomes. J Clin Microbio/ 2003; 41(12): 5517-5524. http://dx.doi.org/10.1128/JCM.41.12.5517-5524.2003. PMid:14662933.

Kuramae-Izioka EE. A rapid, easy and high yield protocol for total genomic DNA isolation of Colletotrichum gloeosporioides and Fusarium oxysporum. Revista UNIMAR 1997; 19(3): 683-689.

Landis JR, Koch GG. The measurement of observer agreement for categorical data. Biometrics 1977; 33(1): 159-174. http://dx.doi. org/10.2307/2529310. PMid:843571.

Laohasinnarong D, Goto Y, Asada M, Nakao R, Hayashida K, Kajino K, et al. Studies of trypanosomosis in the Luangwa valley, north-eastern Zambia. Parasit Vectors 2015; 8: 497. http://dx.doi.org/10.1186/s13071-015-1112-y. PMid:26419347.

Luckins AG. Detection of antibodies in trypanosome-infected cattle by means of a microplate enzyme-linked immunosorbent assay. Trop Anim Health Prod 1977; 9(1): 53-62. http://dx.doi.org/10.1007/BF02297393. PMid:333677.

Machado RZ, Montassier HJ, Pinto AA, Lemos EG, Machado MRF, Valadão IFF, et al. An enzyme-linked immunosorbent assay (ELISA) for the detection of antibodies against Babesia bovis in cattle. Vet Parasito/ 1997; 71(1): 17-26. http://dx.doi.org/10.1016/ S0304-4017(97)00003-4. PMid:9231985.

Madruga CR, Araújo FR, Cavalcante-Goes G, Martins C, Pfeifer IB, Ribeiro LR, et al. The development of an enzyme-linked immunosorbent assay for Trypanosoma vivax antibodies and its use in epidemiological surveys. Mem Inst Oswaldo Cruz 2006; 101(7): 801-807. http://dx.doi.org/10.1590/S0074-02762006000700016. PMid:17160291.

Monzon CM, Mancebo OA, Russo AM. Antibody levels by indirect ELISA test in Trypanosoma evansi infected horses following treatment with quinapyramine sulphate. Vet Parasitol 2003; 111(1): 59-63. http://dx.doi.org/10.1016/S0304-4017(02)00331-X. PMid:12523979. 
Morlais I, Ravel S, Grébaut P, Dumas V, Cuny G. New molecular marker for Trypanosoma (Duttonella) vivax identification. Acta Trop 2001; 80(3): 207-213. http://dx.doi.org/10.1016/S0001-706X(01)00160-7. PMid:11700177.

Moti Y, De Deken R, Thys E, Van Den Abbeele J, Duchateau L, Delespaux V. PCR and microsatellite analysis of diminazene aceturate resistance of bovine trypanosomes correlated to knowledge, attitude and practice of livestock keepers in South-Western Ethiopia. Acta Trop 2015; 146: 45-52. http://dx.doi.org/10.1016/j.actatropica.2015.02.015. PMid:25738729.

Nantulya VM. Trypanosomosis in domestic' animals: the problems of diagnosis. Rev Sci Tech 1990; 9(2): 357-367. http://dx.doi. org/10.20506/rst.9.2.507. PMid:2132685.

Nimitphak T, Kiatpathomchai W, Flegel TW. Shrimp hepatopancreatic parvovirus detection by combining loop-mediated isothermal amplification with a lateral flow dipstick. J Virol Methods 2008; 154(1-2): 56-60. http://dx.doi.org/10.1016/j.jviromet.2008.09.003. PMid:18835299.

Njiru ZK, Ouma JO, Bateta R, Njeru SE, Ndungu K, Gitonga PK, et al. Loop-mediated isothermal amplification test for Trypanosoma vivax based on satellite repeat DNA. Vet Parasitol 2011; 180(3-4): 358-362. http://dx.doi.org/10.1016/j.vetpar.2011.03.021. PMid:21482026.

Osório ALAR, Madruga CR, Desquesnes M, Soares CO, Ribeiro LRR, Costa SCG. Trypanosoma (Duttonella) vivax: its biology, epidemiology, pathogenesis, and introduction in the New World - a review. Mem Inst Oswaldo Cruz 2008; 103(1): 1-13. http:// dx.doi.org/10.1590/S0074-02762008000100001. PMid:18368231.

Pillay D, Izotte J, Fikru R, Büscher P, Mucache H, Neves L, et al. Trypanosoma vivax GM6 Antigen: A Candidate Antigen for Diagnosis of African Animal Trypanosomosis in Cattle. PLoS One 2013; 8(10): e78565. http://dx.doi.org/10.1371/journal.pone.0078565. PMid:24205263.

Pimentel DS, Ramos CA, Ramos RA, de Araújo FR, Borba ML, Faustino MA, et al. First report and molecular characterization of Trypanosoma vivax in cattle from state of Pernambuco. Vet Parasitol 2012; 185(2-4): 286-289. http://dx.doi.org/10.1016/j. vetpar.2011.10.019. PMid:22054681.

Rodrigues AC, Campaner M, Takata CS, Dell' Porto A, Milder RV, Takeda GF, et al. Brazilian isolates of Trypanosoma (Megatrypanum) theileri: diagnosis and differentiation of isolates from cattle and water buffalo based on biological characteristics and randomly amplified DNA sequences. Vet Parasito/ 2003; 116(3): 185-207. http://dx.doi.org/10.1016/S0304-4017(03)00236-X. PMid:14559162.

Rodrigues AC, Garcia HA, Ortiz PA, Cortez AP, Martinkovic F, Paiva F, et al. Cysteine proteases of Trypanosoma (Megatrypanum) theileri: cathepsin L-like gene sequences as targets for phylogenetic analysis, genotyping diagnosis. Parasitol Int 2010; 59(3): 318-325. http://dx.doi.org/10.1016/j.parint.2010.03.002. PMid:20230907.

Sampaio PH, Fidelis OLJr, Marques LC, Machado RZ, Barnabé PA, André MR, et al. Acute-phase protein behavior in dairy cattle herd naturally infected with Trypanosoma vivax. Vet Parasito/ 2015; 211(3-4): 141-145. http://dx.doi.org/10.1016/j.vetpar.2015.05.014. PMid:26012859.

Schrader C, Schielke A, Ellerbroek L, Johne R. PCR inhibitors - occurrence, properties and removal. J Appl Microbiol 2012; 113(5): 1014-1026. http://dx.doi.org/10.1111/j.1365-2672.2012.05384.x. PMid:22747964.

Seidl AF, Dávila AMR, Silva RAMS. Estimated financial impact of Trypanosoma vivax on the Brazilian Pantanal and Bolivian Lowlands. Mem Inst Oswaldo Cruz 1999; 94(2): 269-272. http://dx.doi.org/10.1590/S0074-02761999000200027. PMid:10224541.

Silva RAMS, Eguez A, Morales G, Eulert E, Montenegro A, Ybañez R, et al. Bovine Trypanosomosis in Bolivian and Brazilian Lowlands. Mem Inst Oswaldo Cruz 1998; 93(1): 29-32. http://dx.doi.org/10.1590/S0074-02761998000100006. PMid:9698839.

Tekle T, Terefe G, Cherenet T, Ashenafi H, Akoda KG, Teko-Agbo A, et al. Aberrant use and poor quality of trypanocides: a risk for drug resistance in south western Ethiopia. BMC Vet Res 2018; 14(4): 1-8. http://dx.doi.org/10.1186/s12917-017-1327-6. PMid:29304792.

Toro M, León E, López R, Pallota F, Garcia JA, Ruiz A. Effect of isometamidium on infections by Trypanosoma vivax and T. evansi in experimentally infected animals. Vet Parasito/ 1983; 13(1): 35-43. http://dx.doi.org/10.1016/0304-4017(83)90018-3. PMid:6414154.

Vitouley HS, Sidibe I, Bengaly Z, Marcotty T, Van Den Abbeele J, Delespaux V. Is trypanocidal drug resistance a threat for livestock health and production in endemic areas? Food for thoughts from Sahelian goats infected by Trypanosoma vivax in Bobo Dioulasso (Burkina Faso). Vet Parasitol 2012; 190(3-4): 349-354. http://dx.doi.org/10.1016/j.vetpar.2012.07.015. PMid:22858637.

Whitelaw DD, Gardiner PR, Murray M. Extravascular foci of Trypanosoma vivax in goats: the central nervous system and aqueous humor of the eye as potential sources of relapse infections after chemotherapy. Parasitology 1988; 97(Pt 1): 51-61. http://dx.doi. org/10.1017/S0031182000066737. PMid:3174238. 